Teaching \& Learning (2013/2014) 8(1), 72-86

\title{
Threading the Discussion: A Model to Examine the Quality of Posts in an Online Learning Environment
}

\author{
NANCY MAYNES \\ Schulich School of Education, Nipissing University \\ BLAINE E. HATT \\ Schulich School of Education, Nipissing University
}

\begin{abstract}
The design of online learning courses offered in a teacher education program and with post-graduate degrees in education, varies greatly by course focus, instructor experience, and availability of suitable and accessible platform software. Many online course instructors include asynchronous topic-based discussions in their course expectations for students. However, it is an ongoing discussion among the online professorship as to ways they might encourage increased depth and thoughtful contributions to the online community's learning by engaging in threaded online discussions. This paper provides an overview of a model for online learning, as derived from recent research, and proposes a framework for examining two aspects of online discussion threads that may be posted by student participants. First, a framework is provided that might be given to online student participants to guide their contributions to the discussions. Second, a list of possible contents of online discussions is presented, and suggestions are made for how the online professorship might use this list of possibilities to guide peer and self-evaluation of online contributions.
\end{abstract}

\section{Introduction}

Increasingly, schools and universities are offering courses through online options (Siemans, 2006). Many online courses include elements of interaction among participants through threaded discussions around a topic that is identified by the instructor, or through topics of interest identified by the course participants (Maynes \& Hatt, 2013). Since course instructors expect this interaction among online course participants to provide evidence of each participant's engagement with the course topics, they need to be able to evaluate the frequency and quality of the online discussions for their courses. While determining frequency of posts to an online discussion is a simple matter of counting, determining the quality of these posts is a much more complex instructional task, requiring clear conceptions of the possibilities on the part of the instructor, and clear communication of these possibilities to the online course participants. The 
model and frameworks that are included in this paper provide references and guidance to help online professors plan and execute careful and constructive evaluation of the quality of online posts in threaded discussions.

\section{Literature Review}

\section{Social Constructivist Pedagogy}

Modern educational pedagogy promotes a collaborative approach to learning (Freire, 1990, 1994; Hardwick, 2000; Jeffries, 2003; McConnell, 2000; Senior, 2010). This is equally true of learning that takes place online (Maynes \& Hatt, 2013). In fact, online course instructors stress the importance of maintaining their philosophy of instruction and working toward adapting the capacities of online environments, so that they provide the convenience of online approaches with the strengths of face-to-face venues for learning. In a well-structured online environment, instructors can ensure that they have provided for learning that happens in ways that support social constructivism (Piaget, 1950; Vygotsky, 1978).

In the post-secondary social constructivist context, the professor is a facilitator of student knowledge and guides students through the course in a learner-centered manner (Boyd, 2006; Fox, 2005; Jeffries, 2003; McConnell, 2000). However, in a professor-student relationship, there is generally the pre-conceived notion that the professor is more knowledgeable than the student, and that it is the educator's responsibility to convey knowledge to the student (Fairclough, 2001). This scenario can create an imbalance in power between the professor and the student (McConnell, 2000), where information flows in one direction, from teacher to learner. However, through thoughtful management of threaded discussions in an online environment, professors can ensure that the social constructivist nature of student-to-student and student-to-professor exchanges maintain both tone and depth of thought to support constructivism. To achieve this goal, the professor needs a conception of the possibilities that outline qualities that should be present in deep thinking in an online environment.

\section{From Constructivist to Connectivist}

An online learning environment can redefine the relationship between the professor and the students, creating a new kind of learnership that demands new pedagogical skills and conceptions among the online professorship. Due to rapidly changing technology, and easier 
access to knowledge through the Internet, there have been changes to traditional educational pedagogies (Siemens, 2006). In this evolving approach, constructivist beliefs and technological capabilities come together to provide opportunities for connections among students, and between the students and their professor that are unlike any previous academic interactions. This approach is being referred to as a connectivist approach. To support and maintain connectivist interaction in the discussions that take place online, professors and their students would benefit from clear conceptions about how to engage in self, peer, and professor evaluations of the quality of their contributions to online threads.

Recent pedagogy, in the area of distance education, promotes a connectivist approach, where students interact through networks and social media (Anderson \& Dron, 2011; Connolly, 2007; McConnell, 2000). In a connectivist approach, the emphasis is on finding sources to access information, as opposed to memorization of content (Anderson \& Dron, 2011). Educators and students collaborate, and learning ebbs and flows among all parties engaged in the online environment (Siemens, 2006; McConnell, 2000), creating a more open learning society (Fox, 2005; Gibbons, 2000). In a connectivist learning environment, the professor and the students learn together. However, this type of connectivist learning can only happen when all participants in threaded discussions have a clear and commonly understood conception of how to assess the quality of online contributions.

Social constructivist pedagogy in an online environment (Jeffries, 2003; McConnell, 2000; Walton, 2000) can be achieved through both asynchronous and synchronous interactions between students and professors. The use of blackboard and/or email (Anderson \& Dron, 2011; McConnell, 2000) provides a social medium where educators can facilitate learning, rather than deliver it, by actively engaging learners. While such interaction creates connectivist possibilities, it also creates unique challenges. Because of changes in pedagogy toward more student-centered learning, and changes in technology toward more online opportunities, the educator's role is also changing (Senior, 2010). Educators cannot expect to simply transfer content and/or pedagogical practices from face-to-face courses, into an online learning environment without re-organizing the course material and re-structuring course delivery (Connolly, Jones, \& Jones, 2007; Garrison, Cleveland-Innes, \& Fung, 2004; Jeffries, 2003), or without a clear idea, clearly communicated to students, about the nature of valuable contributions to threaded discussions. By restructuring materials and delivery, a connectivist environment might be achieved. It may be challenging for 
many professors who are new to the online course delivery environment to adapt their practices to teach effectively. Online requirements may seem counter-intuitive to traditional face-to-face beliefs about relationships with students and the social aspects of learning, when combined with the limitations and opportunities presented by the available technology.

It is important for educators to develop a relationship with their students to provide optimal learning experiences in any learning environment. This is a bigger challenge for professors in the online learning format, as there is generally little or no face-to-face interaction. Therefore, a professor must rely upon language as the medium to convey the message (Garrison, 2004; McConnell, 2000; Harris, 1970). For the most part, the discourse between the professor and the student will be through the written word, which according to Plato "cannot be defended when misunderstood” (Freire, 1990). Therefore, it is imperative that the professor is clear and coherent through the written word to avoid any misinterpretations, or misunderstanding, on the part of the student (Fairclough, 2001). In addition, the written word is absent of physical gestures, and pedagogical glances that help develop an educator-student relationship (Saevi, 2011; Hatt, 2005; Garrison, 2004; McConnell, 2000; Ryan, 1972). Some authors believe that, through language, the professor and the student can experience a more equalized balance of power (Fox, 2005), but other authors believe that dialogue does not create equality; instead it creates a feeling of Other (Saevi, 2011; Hatt, 2005; Carter \& Rukholm, 2002; Fairclough, 2001; McConnell, 2000; Freire, 1992).

Written communication is essential in an online learning environment. It is through dialogue, which is mainly in written form in online courses, that the teacher-student relationship is developed, trust is established (Freire, 1990), and knowledge is shared (Boyd, MacNeill, \& Sullivan, 2006). While few studies have looked at the effect of such collaborative pedagogy on post-secondary students (Shoffner, 2009; Hardwick, 2000), some studies have shown the unique advantages of online learning in other course contexts. Well-managed online dialogue provides an increased feeling of community (Carter, 2008; McConnell, 2000), opportunities for students to improve written skills (Carter, 2008), increased time to respond, more equality among genders, no interruptions, and a permanent record of responses (McConnell, 2000). Through online courses, students also experience increased confidence in their writing abilities, and become more comfortable with the online learning environment (Carter, 2002). 
Effective written communication assists in the creation of a community of learnership that is essential in an online learning environment. Our society is made up of naturally forming communities of practice (Fox, 2005, Bruffee, 1973), and the online learning environment is no exception. Pedagogy, language, and technology all combine to create communities of learnership (Garrison, 2004). A community of learnership is foundational to connectivist learning.

The drop-out rates in online learning are higher than in face-to-face environments, primarily because of the physical separation of participants (Senior, 2010). However, it may be that this trend can be reversed by closely examining the professor's role, as facilitator and organizer, in the creation of a community of learnership where students can feel a sense of belonging (Connolly, 2007; McConnell, 2000; Bruffee, 1973). By creating a learnership environment where expectations are clear, interactive comfort is mediated, and diverse ways of learning and interests are supported, the professor can facilitate learning, thereby encouraging students to take responsibility for their own learning (Garrison, 2004; Jeffries, 2003; McConnell, 2000); interact successfully with other course participants (Mashhour \& Saleh, 2010); and, create a community of learnership (Connolly, 2007) that meets their learning needs. Such a community has the potential to engender a commitment to collaborative pedagogy that can be negotiated and supported effectively through the online dialogue between professor and students, and among students.

What is abundantly clear from previous research is that the quality of threaded online discussions matters to the quality of the online course. This paper provides a framework to help the online professorship analyze the quality of discussion contributions made by their students.

\section{Threading to Keep Online Discussions Sharp}

Recent research into the need for high quality online discussions among course participants (Maynes \& Hatt, 2013) has resulted in the development of a visual model for online learning. This model displays the progression of threaded discussions in an online environment, moving from an initial social presence online toward deeper contribution to self- and peerlearning in a community of learnership. The model is included here as Figure 1. The details of the model are explained in the previous research. 


\section{Model for Online Course Delivery}

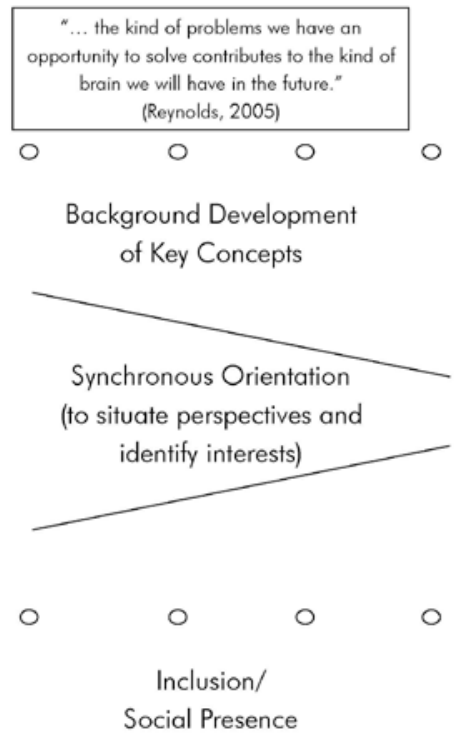

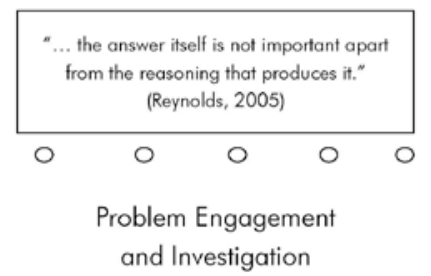

Asynchronous Interest Sub-Theme Interaction

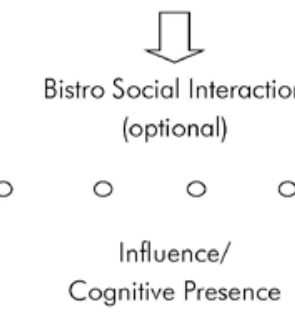

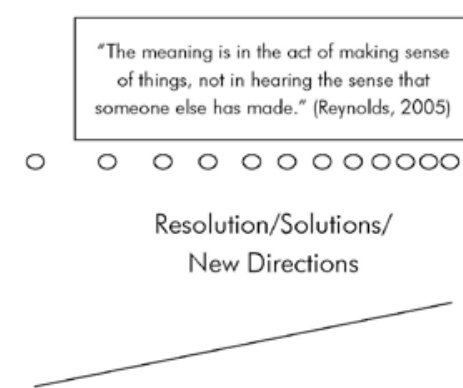

Synchronous Reflection and Summation of Course Themes

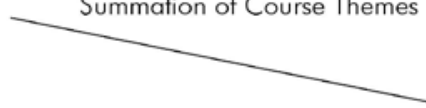

- 0000000000 Community/ Teaching and Constructing New Understanding Presence

Figure 1: Model for Online Course Delivery

However, for many online professors, it can be challenging to find ways to communicate clear expectations to students about how to contribute to discussions effectively. When these online discussions occur among course participants in a way intended to build on previous comments, online learners refer to these contributions as threads. This paper provides two frameworks for the following applications: 1) to show students the possible ways they can respond to threaded discussions (i.e., to help online students self-evaluate their discussion contributions); and 2) to identify a range of content foci that may be central to the development of an individual's contribution to a threaded discussion (i.e., to help professors evaluate the quality of each student's online contributions). Together, these two frameworks can help professors understand how to develop criteria for examining and improving the quality of threaded discussions in their courses. When range and quality characteristics are clear to the professor, they can then be made clear to students. In public school contexts, such clarity of expectations is referred to as success criteria.

\section{Responding to Threaded Discussions Online}

In an online learning environment, the threaded discussions among the students and between the students and the professor, can have three main purposes. These may include: social 
interaction that shows presence online, attempts to influence the cognitive understanding of concepts, and efforts to teach others and construct new understanding in a community of learnership. As shown in Figure 1, a well-managed online course should help students move across these three purposes as the course progresses. We contend that this movement is most likely to happen if course participants are aware from the outset that such movement is expected of them. By providing students with the online learning model (Figure 1) at the outset of the course, and by engaging students in a discussion about expectations that their contributions should evolve in quality as the course progresses, professors are most likely to ensure this outcome.

Similarly, course participants should understand that there are predicable sets of ways that they can respond to other participants in a threaded discussion. These parallel the growth of discussion quality as shown in Figure 1. As a social presence, online threads could support another writer, give credit for an idea, or attend to logistical details such as forming working groups. These are all ways to recognize group members by including them socially. Cognitive interactions in threaded discussions could include challenging ideas expressed by other contributors, or exploring possibilities in a "think aloud" voice. As participants engage in coconstructing meaning through threaded discussions, their posts may include expansions on the ideas posted by others, offers of alternative perspectives, and the synthesis of ideas garnered from a string of posts about a single topic (see Figure 2). Connectivism is achieved as participants begin to co-construct meaning.

\begin{tabular}{|c|c|}
\hline Nature of Online Contribution & Sample of Contribution of this Nature \\
\hline Inclusion / Social Presence & $\begin{array}{l}\text { - } \text { support an idea offered by another } \\
\text { person } \\
\text { - } \quad \text { give someone credit for an idea } \\
\text { - } \text { attend to logistical details }\end{array}$ \\
\hline Cognitive Presence / Influence & $\begin{array}{l}\text { - challenge ideas expressed by other } \\
\text { contributors } \\
\text { - explore possibilities in a "think } \\
\text { aloud" voice }\end{array}$ \\
\hline $\begin{array}{l}\text { Teaching and Constructing New } \\
\text { Understanding Presence in a Community of } \\
\text { Learnership }\end{array}$ & 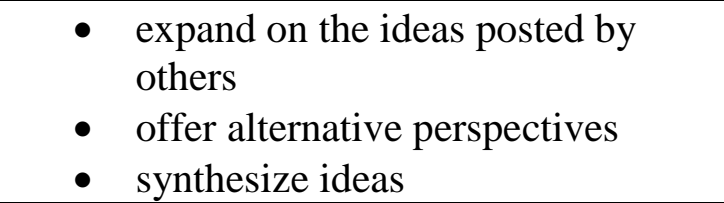 \\
\hline
\end{tabular}

Figure 2: Transitioning from Social Presence to Social Connectivism in Threaded Online Discussion 


\section{Providing Specific Feedback about Online Posts}

Once professors identify the level of online posts they see in threaded discussions, they are able to provide specific and individual support to students in the form of feedback. Feedback will be most helpful to support students' growth if it is timely and specific to what each student has contributed to the threaded discussions. To provide such feedback, once again professors must consider the possibilities and provide feedback that names what they observe, and identifies how this contribution could be strengthened by naming the possibilities.

Professors might use the following list of online thread characteristics to help them identify what they see in their students' threaded discussions. They should consider if their students' contributions do any (or any combination of) the following:

Note: Each type of contribution is followed by a coded short form that professors might use to analyze the types of contributions made by students.

- $\quad$ solving problems (SP)

- requesting information (RI)

- requesting examples and exemplars (RE)

- $\quad$ seeking experience among participants (SE)

- making “expert” contacts (within or outside the course group) (MEC)

- reusing resources and previous knowledge (RR)

- coaching others (CO)

- $\quad$ acquiring resources (AR)

- making conceptual connections (MCC)

- building a sense of community through cognition (BCC)

- building a sense of community through social engagement (BCSE)

- $\quad$ testing the validity of new ideas (TVNI)

- coordination of efforts and ideas (CEI) 
- creating synergy and interest in new directions (CS)

- linking theory and practice (LTP)

- creating other ways of displaying understanding (e.g., visual models) (WDK)

- discussing developments (DD)

- creating records and summaries (CRS)

- documentation and referencing (DR)

- collaborating (C)

- clarifying personal understanding (CPU)

- making connections to previous learning (MCPL)

- making connections to other's ideas (MCOI)

- making social and personal connections (MSPC)

- expanding personal and professional skills (EPPS)

- clarifying criteria (CC)

- bridging between criteria and success criteria (BCSC)

- mapping personal and group knowledge (MPGK)

- identifying gaps in knowledge (IGK)

- making plans to address gaps in knowledge (MPAG)

- seeking mentors (SM)

- seeking online friends (SOF)

Using the organizer provided in Figure 2, these online thread characteristics can be related to each of the three types of online contributions. Appendix A connects these characteristics with each of the types of contributions.

It is likely that a single post will include many of the elements of online interaction that are identified in this list. By being able to code the types of interactions that are typical for each 
participant, professors can build their own understanding of how each student is progressing along the continuum of social, to cognitive, and community of learnership interaction as a course progresses.

\section{Self - Peer and Professorial Evaluation of Online Threaded Discussions}

If the online student does not understand the criteria that professors want to characterize their course discussions, they are unlikely to achieve any consistent success in attaining high quality interaction. In order to have threaded discussions contribute to building a community of learnership in an online environment, everyone involved in the community needs to know what is expected and what evidence will be used to examine each participant's contribution to achieving that goal.

To help students understand the value of effective online threads, they will need to understand that they are likely to evolve through the predictable stages of online interaction as shown in Figure 1 (i.e., social presence, cognitive presence, teaching/community of learners presence). Additionally, they should have opportunities to evaluate their own contributions to online discussions. The framework provided in Figure 2 would help students consider various contributions to online discussions as contributions to the goal of creating a community of learnership. Similarly, course participants can be taught to self-evaluate their threads for specific content, using the codes for threaded characteristics provided in the previous section of this paper. Both of these practices will help course participants understand and appreciate the quality of threads that will be the best contributors to building the community of learnership. Appendix B shows a self-evaluation or instructor friendly form that might be used to guide this evaluation of the discussion threads.

No doubt as we develop our expertise with online learning at the undergraduate and graduate levels, professors will expand on this model and on these characteristics to help all online instructors become even more effective with managing threaded discussions to support effective learning.

Dr. Nancy Maynes is an Associate Professor in the Schulich School of Education at Nipissing University. Her research interests include teacher education and professional growth, specifically 
aspects of teacher education that influence strategy efficacy, service learning, professional reflection, and the internalization of key curriculum concepts.

Dr. Blaine Hatt is an Associate Professor in the Schulich School of Education at Nipissing University, involved in research in Arts and Education, Alternative Education, Imagination Creativity Education, Curriculum and Instruction, and Educational Administration.

\section{References}

Anderson, T., \& Dron, J. (2011). Connectivism: Design and delivery of social networked learning. Three generations of distance education pedagogy. The International Review of Research in Open and Distance Learning, 12(3).

Boyd, R., MacNeill, N., \& Sullivan, G. (2006). Relational pedagogy: Putting balance back into students' learning. Retrieved from: http://www.curriculum.edu.au/leader/articles,57.html?issueID=10277

Bruffee, K. A. (1973). Collaborative learning: Some practical models. College English, 34(5), 634-643.

Carter, L., \& Rukholm, E. (2002). Online scholarly discourse: Lessons learned for continuing and nurse educators. Canadian Journal of University Continuing Education, 28(2), 33-50.

Carter, L. (2008). Perceptions of writing confidence, critical thinking, and writing competence among registered nurse-learners studying online. Canadian Journal of University Continuing Education, 34(2), 63-87.

Christensen, C., Horn, M., \& Johnson, C. (2008). Disrupting class: How disruptive innovation will change the way the world learns. New York, NY: McGraw-Hill.

Connolly, M., Jones, C., and Jones, N. (2007). New approaches, new vision: Capturing teacher experiences in a brave new online world. Open Learning, 22(1), 43-56.

Creswell, J. W. (2012). Educational research: Planning, conducting, and evaluating qualitative and quantitative research ( $4^{\text {th }}$ ed.). Newmarket, ON: Pearson.

Duncan, H., \& Barnett, J. (2010). Experiencing online pedagogy: A Canadian case study. Teaching Education, 21(3), 247-262.

Fairclough, N. (2001). Language and power ( $2^{\text {nd }}$ ed.). London, UK: Pearson Education Harlow.

Fox, S. (2005). An actor-network critique of community in higher education: Implication for networked learning. Studies in Higher Education, 30(1), 95-110.

Freire, P. (1990). Pedagogy of the oppressed. (M. B. Ramos, Trans.). New York, NY: Continuum.

Freire, P. (1994). Pedagogy of hope: Reliving pedagogy of the oppressed. (R. R. Barr, Trans.). New York, NY: Continuum.

Garrison, D. R., Cleveland-Innes, M., \& Fung, T. (2004). Student role adjustment in online communities of inquiry: Model and instrument validation. Journal of Asynchronous Learning Networks, 8(2), 61-74.

Gibbons, M. (2000). Context-sensitive science: Mode 2 society and the emergence of contextsensitive science. Science and Public Policy, 27(3), 159-163.

Hardwick, S. W. (2000). Humanising the technology landscape through a collaborative pedagogy. Journal of Geography in Higher Education, 24(1), 123-129. 
Harris, T. E. (1970). Understanding McLuhan: An extension of rhetoric. U. S. Department of Health \& Welfare National Institute of Education. Retrieved from http://eric.ed.gov/?id=ED093030

Hatt, B. E. (2005). Pedagogical love in the transactional curriculum. Journal of Curriculum Studies, 37(6), 671-688.

Jeffries, P. (2003). ICT in supporting collaborative learning: Pedagogy and practice. Journal of Educational Media, 28(1), 35-48.

Mashhour, A., \& Saleh, Z. (2010). Evaluating e-learning in Jordanian institutions. Why is it lagging? Quarterly Review of Distance Education, 11(4), 269-279.

Maynes, N., \& Hatt, B. E. (2013). Online learning: Growing into our capacity for flexible learning. Journal of Transformative Entrepreneurship, 1(2), 83-92.

McConnell, D. (2000). Implementing computer supported cooperative learning $\left(2^{\text {nd }}\right.$ ed.). London, UK: Kogan Page.

Ontario Ministry of Education and Training (2005). Education for all: The report of the expert panel on literacy and numeracy instruction for students with special education needs, Kindergarten to Grade 6. Toronto, ON: Queen's Printing.

Ontario Ministry of Education and Training (2009). Learning for all: A guide to effective assessment and instruction for all students, Kindergarten to Grade 12. Toronto, ON: Queen's Printing.

Piaget, Jean. (1950). The psychology of intelligence. New York, NY: Routledge.

Reynolds, S. (2005). Learning is a verb: The psychology of teaching and learning. Scottsdale, AZ: Holcomb Hathaway Publishers.

Ryan, M. G. (1972). The social ancestry of Marshall McLuhan’s theories. U. S. Department of Health \& Welfare National Institute of Education. Retrieved from: http://www.eric.ed.gov/ERICWebPortal/contentdelivery/servlet/ERICServlet?accno=ED 089386

Saevi, T. (2011). Lived relationality as fulcrum for pedagogical-ethical practice. Studies in Philosophical Education, 30, 455-461.

Senior, R. (2010). Connectivity: A framework for understanding effective language teaching in face-to-face and online learning communities. RELC Journal, 41(2), 137-147.

Shoffner, M. (2009). The place of the personal: Exploring the affective domain through reflection in teacher preparation. Teaching and Teacher Education, 25, 783-789.

Siemens, G. (2006). Connectivism: Learning theory or pastime of the self-amused? Retrieved from: http://scholar.google.ca/scholar?q=Connectionist+theory +Siemens\&hl=en\&as_sdt=0\&as_vis=1\&oi=scholar

Vygotsky, L. S. (1978). Mind in society. Cambridge, MA: Harvard University Press.

Walton, R. (2000). Heidegger in the hands-on science and technology center: Philosphical reflections on learning in informal settings. Journal of Technology Education, 12(1), 4960.

Watson, J. (2007). A national primer on K-12 online learning. Washington, DC: North American Council on Online Learning.

Watson, J. F., Gemin, B., and Ryan, J. (2008). Keeping pace with K-12 online learning: A review of state-level policy and practice. Vienna, VA: North American Council for Online Learning. Retrieved from:

http://www.kpk12.com/downloads/KeepingPace_2008.pdf 
Appendix A: Connecting Online Contribution Types and Thread Characteristics

\begin{tabular}{|c|c|c|}
\hline $\begin{array}{l}\text { Nature of Online } \\
\text { Contribution }\end{array}$ & $\begin{array}{l}\text { Sample of Contribution } \\
\text { of this Nature }\end{array}$ & Online Thread Characteristics \\
\hline $\begin{array}{l}\text { Inclusion / Social } \\
\text { Presence }\end{array}$ & $\begin{array}{ll}\text { - } & \text { support an idea } \\
\text { offered by } \\
\text { another person } \\
\text { - } \\
\text { give someone } \\
\text { credit for an } \\
\text { idea } \\
\text { - } \quad \text { attend to } \\
\text { logistical details }\end{array}$ & $\begin{array}{ll}- & \text { requesting information (RI) } \\
\text { - } & \text { building a sense of community } \\
\text { - } & \text { collaborating (C) } \\
\text { - } & \text { making social and personal } \\
& \text { connections (MSPC) } \\
\text { - } & \text { seeking online friends (SOF) }\end{array}$ \\
\hline $\begin{array}{l}\text { Cognitive } \\
\text { Presence / } \\
\text { Influence }\end{array}$ & $\begin{array}{l}\text { - challenge ideas } \\
\text { expressed by } \\
\text { other } \\
\text { contributors } \\
\text { - explore } \\
\text { possibilities in a } \\
\text { "think aloud" } \\
\text { voice }\end{array}$ & 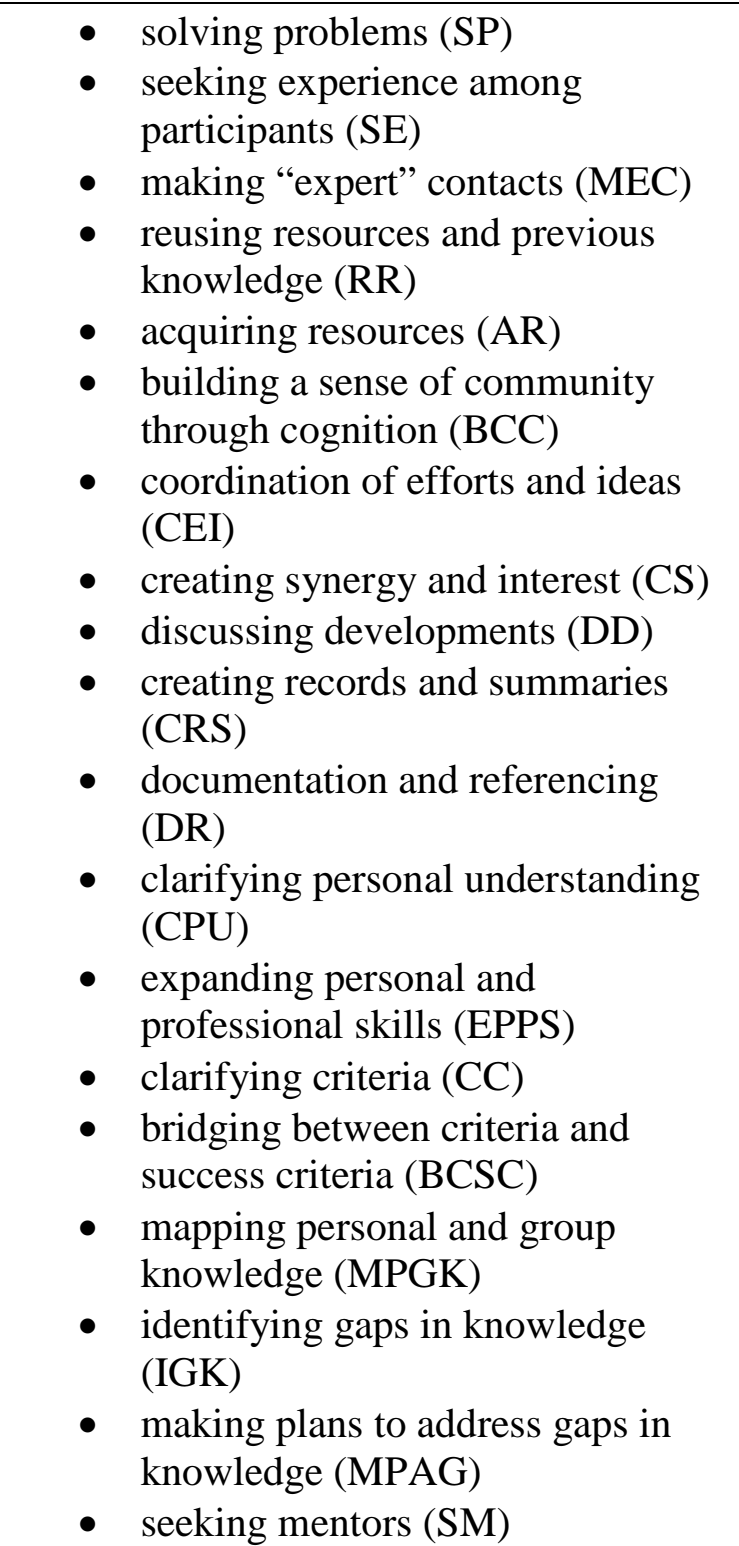 \\
\hline
\end{tabular}


Threading the Discussion

\begin{tabular}{|c|c|c|}
\hline $\begin{array}{l}\text { Teaching and } \\
\text { Constructing } \\
\text { New } \\
\text { Understanding } \\
\text { Presence in a } \\
\text { Community of } \\
\text { Learnership }\end{array}$ & 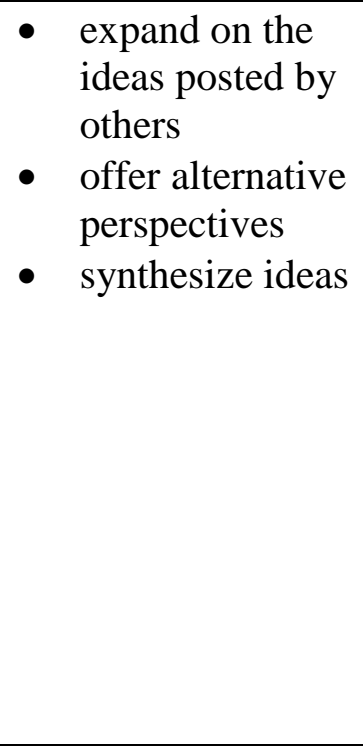 & $\begin{array}{ll}\text { - } & \text { requesting examples and } \\
\text { - } & \text { coachplars (RE) } \\
\text { - } & \text { making conceptual connections } \\
& \text { (MCC) } \\
\text { - } & \text { testing the validity of new ideas } \\
& \text { (TVNI) } \\
\text { - } & \text { linking theory and practice (LTP) } \\
\text { - } & \text { creating other ways of displaying } \\
\text { understanding (e.g., visual models) } \\
\text { (WDK) } \\
\text { - } \text { making connections to previous } \\
\text { learning (MCPL) } \\
\text { making connections to other's } \\
\text { ideas (MCOI) }\end{array}$ \\
\hline
\end{tabular}




\section{Appendix B: Online Learning Participation Assessment}

\section{Online Learning Participation Assessment}

\section{Course Participant:}

Online posts will be evaluated by the course instructor based on the following framework. As well, course participants are required to provide a self-evaluation of their contribution to the online discussions.

Participants should see the framework as a developmental sequence that should evolve as the group engages in learning together. Indicators (right hand column) will be used to assess the contribution of each post to the learning of all course participants.

A minimum of 2 posts per week is required.

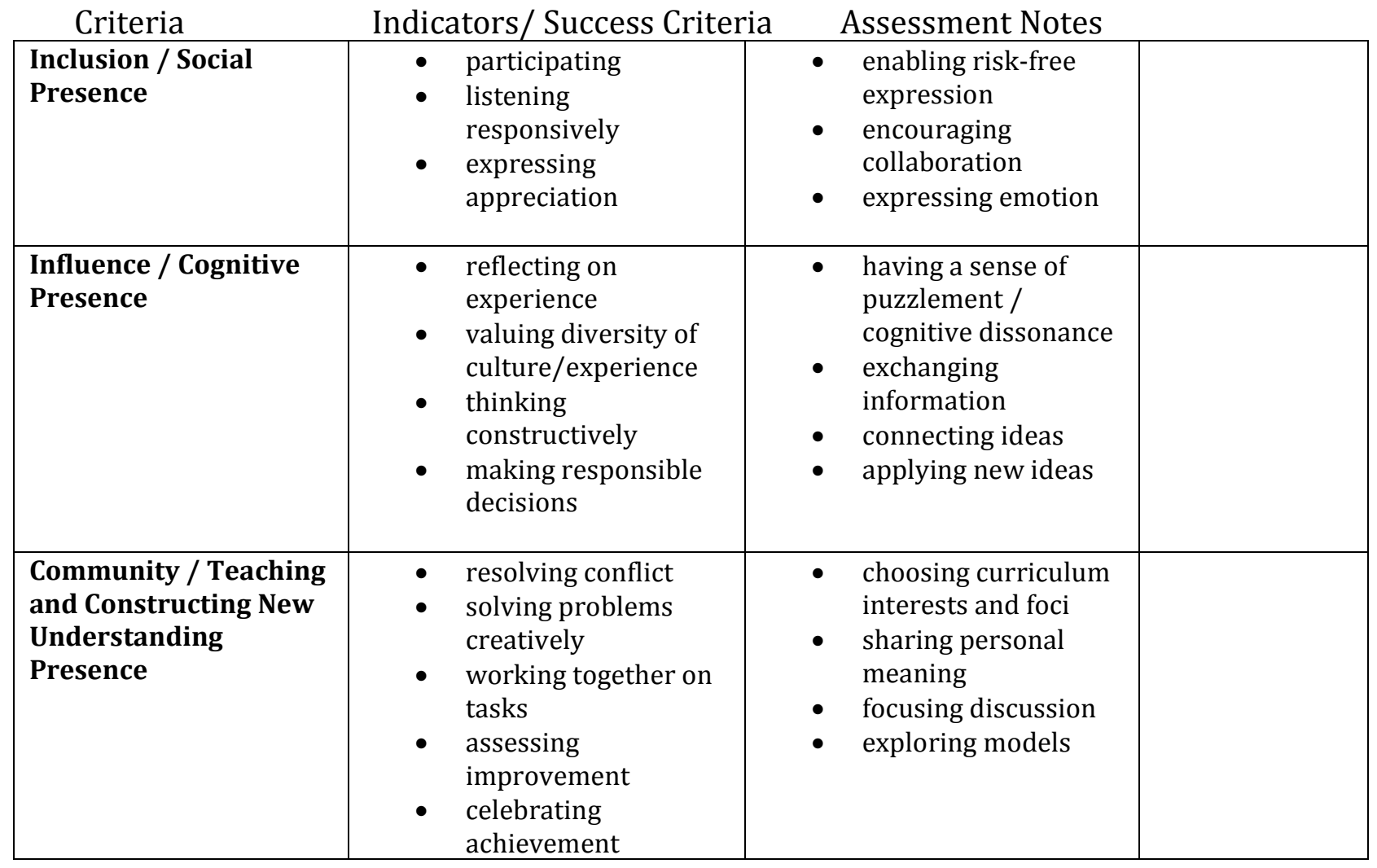

